\title{
Biomass yield and growth allometry of some crops growing under weed stress
}

\author{
SAIRA QADIR ${ }^{1}$, AFSHEEN KHAN ${ }^{1,2, \boldsymbol{v}}$, IRAM US SALAM ${ }^{1}$ \\ ${ }^{1}$ Department of Botany, Federal Urdu University of Arts, Science and Technology. University Rd, Block 9, Gulshan-e-Iqbal, Karachi 73500, Pakistan \\ ${ }^{2}$ Dr. Moinuddin Ahmed Research Laboratory of Dendrochronology and Plant Ecology, Department of Botany, Federal Urdu University of Arts, Science \\ and Technology. University Rd, Block 9, Gulshan-e-Iqbal, Karachi 73500, Pakistan. "email: authors@ smujo.id
}

Manuscript received: 20 September 2020. Revision accepted: 17 November 2020.

\begin{abstract}
Qadir S, Khan A, Salam IU. 2020. Biomass yield and growth allometry of some crops growing under weed stress. Biodiversitas 21: 5621-5629. The conventional approach in crop science generally focuses on nutritional yield of crops. Crop yield is basically ranked by its photosynthetic efficiency. Hence the higher reserves of photosynthetic products are achieved in the form of biomass. Current study explains the gain and loss in biomass of five different crops viz, Zea mays L. (maize), Hordeum vulgare L. (barley), Cicer arietinum L. (chickpea), Pisum sativum L. (pea) and Phaseolus vulgaris L. (French beans) treated by weed manure of Portulaca oleracea L., Euphorbia hirta L. and Amaranthus viridis L. at 5\%, 10\% and 15\% concentration. The inhibitory effects of the given weeds persist with significant ( $\mathrm{p}<0.5)$ differences in the biomass of tested crops. Absolute growth rate (AGR), relative growth rate (RGR) and carbon content are highest $\left(29.43 \mathrm{mg} \mathrm{day}^{-1}, 2.43 \mathrm{mg} \mathrm{gm}^{-1} \mathrm{day}^{-1}\right.$ and $15.25 \%$ respectively) in Chickpea plants induced by $5 \%$ P. oleracea extract. The highest inhibition recorded in Pea plants induced by $15 \%$ of $A$. viridis extract with $8.33 \mathrm{mg} \mathrm{day}^{-1}, 1.42 \mathrm{mg}$ $\mathrm{gm}^{-1} \mathrm{day}^{-1}$ and $4.67 \%$ of AGR, RGR and carbon yield respectively. Inhibition rate of weeds on leaf growth indices also exists in the same order i.e., the highest in A. viridis and the lowest in $P$. oleracea. Therefore, it is concluded that $A$. viridis has produced the highest level of inhibition among the three weeds while Pea species is the most sensitive crop species among the five tested crops.
\end{abstract}

Keywords: Absolute growth rate, Relative growth rate, growth indices, biomass, allelopathy

Abbreviations: AGR: Absolute growth rate, DW: Dry weight, ERGR: Estimated relative growth rate, FW: Fresh weight, LA: Leaf area, LAI: Leaf area index, NAR: Net assimilation rate, PL: Plant length, RGR: Relative growth rate, SRGR: Standard relative growth rate, STDev: Standard deviation

\section{INTRODUCTION}

Biomass is a fundamental source of renewable energy that comes from organic matter stored in a living body (plants and animals). In plants, it is regarded as biomass, obtained as a result of metabolic processes and reserves in the form of carbon content (Asad et al. 2020). It could be derived from any part of the plant i.e., leaves, nutshells, fruit seeds, bark, etc. and widely used as bio-fuel. Organic biomass is biodegradable and serves as an eco-friendly resource for various forms of energy and material ( $\mathrm{Li}$ et al. 2018). Moreover, biomass plays a great role in agriculture by lowering the chance of soil to erode due to its high carbon content (Khan et al. 2018). However, these carbon products are reusable by the plants at the time of need for synthesizing different bio-chemicals inside the plant body during unfavorable conditions (Zhu et al. 2010).

Usually, forests are considered as the biggest carbon source because of huge tree biomass as a contribution to the environment (Khan et al. 2020), while agriculture fields also contribute to maintenance of carbon sinks (Thomas and Martin 2012). Hood et al. (2012) explained that cereal crops (wheat, maize, sorghum, barley) may provide the highest proportion of biomass in the production of biogas which can be further converted into carbon compounds. Similarly, pulses especially chickpea, garden pea, and
French beans which are the richest source of gluten, provide a significant path for high content of biomass due to its rapid photosynthetic rate (Kumar and Yadev 2018).

Basically, biomass is backup energy of plants that provides strength to cope with any stressful or unfavorable condition. Whereas biomass production itself suffers through various uncertainties like contamination of different compounds such as phenolic compounds, other biostimulants from neighbor plants. According to Zohaib et al. (2017), allelochemicals present in the leachates and powder of certain weeds are threatening to germination capability, height, yield, and biomass production of the wheat crop. However, the reduction in biomass acquisition usually occurs as a result of delayed photosynthesis and cell division and there are certain phytochemicals (ferulic, caffeic, and hydroxybenzoic acid) are also involved which cause inhibition in these processes (Abbas et al. 2014).

Present work explains the extent of biomass accumulation in crops, i.e. Zea mays L. (maize), Hordeum vulgare L. (barley), Cicer arietinum L. (chickpea), Pisum sativum L. (pea) and Phaseolus vulgaris L. (French beans), when grown under weed stress. It also adds up a hypothetical approach based on current findings to evaluate the effectiveness of weed influence on biomass production rate of some important crops in an agricultural field. 


\section{MATERIALS AND METHODS}

Experimental work was carried out from January 2019 to December 2019 by following control randomized block design at greenhouse and agriculture field in the Botany Department, Federal Urdu University of Arts, Science and Technology, Karachi, Pakistan.

\section{Weed selection criteria}

Portulaca oleracea is a succulent weed and stores highest amount of phenols in it, these phenols could reduce the growth attainment efficiency of common beans at higher levels of weed powder (El-Rokiek 2013). Euphorbia hirta is a cosmopolitan weed and could leach out certain biochemicals that are noxious to other crops while manure of this weed drastically influenced the growth, biomass densities of leguminous crops including chickpea, soya bean, and common beans (Tanveer et al. 2013). Amaranthus viridis is known to have widespread distribution worldwide, and contained allelochemicals in a large quantity that produce drastic effects on plant height, leaf area, fresh and dry masses on most of the species of Poaceae family including Maize, Barley, Wheat, Pearl millet (Dafaallah et al. 2019). Massive occurrence of predefined weeds in the locality was a major reason to study their relative impact on biomass of frequently grown crops in the region.

\section{Experimentation}

For manure preparation, mature plants of $P$. oleracea, E. hirta and A. viridis were collected from several areas of Karachi and brought to the laboratory for air drying. When all the weeds were completely dried they were ground separately with help of Willey Mill to transform the dried material into coarse powder. These powdered varieties were stored in their respectively labeled glass jars to avoid contamination. Five-hundred grams of total volume maintained for soil mixed with the obtained plant powder of $P$. oleracea, E. hirta, and A. viridis. Soil was prepared in different concentrations of weed powder i.e., $5 \mathrm{~g}, 10 \mathrm{~g}$, and $15 \mathrm{~g}$. The various soil concentrations were placed in their respectively marked pots along with the replicates (five replicates for each treatment and control). Soil texture was composed of sandy loam soil with natural humus fertilizer in 8:2 ratio. Control pots were filled with $500 \mathrm{~g}$ of soil only. Ten surface-sterilized seeds of Zea mays (maize), Hordeum vulgare (barley), Cicer arietinum (chickpea), Pisum sativum (pea) and Phaseolus vulgaris (French beans) were sown in their marked pots. The pots were kept in greenhouse for 3-4 days and were irrigated properly, brought to the open field for 12 weeks. When each plant reached maturity, they were uprooted and brought to the laboratory for further analysis.

Each crop plant treated with different amount of weed powder was firstly washed with tap water to eliminate sand particles. The plant height and leaf area were measured with help of measuring scale, while fresh weight and dry weights were recorded with help of digital balance TE 214 S. Dry weight of plants was recorded after keeping plants in paper bag for a few days.

\section{Statistical analysis}

Growth rates were evaluated using the formulas presented below according to Paine et al. (2012); Blackman (1919) for Absolute growth rate (AGR) and Relative growth rate (RGR). Leaf parameters including leaf area index (LAI) and n $E_{R G R}=E_{\ln } W_{2}-E_{\ln } W_{1} / t_{2}-t_{1}$ et assimilation rate (NAR) were evaluated by following Rajput et al. (2017); Asad et al. (2020). Simulated formulation was developed according to Poorter and Garnier (1998):

$$
\begin{aligned}
& A G R=M_{2}-\mathrm{M}_{1} / \mathrm{t}_{2}-\mathrm{t}_{1} \\
& N A R=\left(W_{2}-W_{1}\right)\left(\log L_{2}-\log L_{1}\right) /\left(t_{2}-t_{1}\right)\left(L_{2}-L_{1}\right) \\
& R G R=\ln \left(M_{2}\right)-\ln \left(M_{1}\right) / t_{2}-t_{1}
\end{aligned}
$$

Leaf Area Index (LAI): Total leaf area/Shoot length

$$
N A R=\left(W_{2}-W_{1}\right)\left(\log L_{2}-\log L_{1}\right) /\left(t_{2}-t_{1}\right)\left(L_{2}-L_{1}\right)
$$

Where, $\mathrm{M}_{2}$ : Total final dry weight (mg), $\mathrm{M}_{1}$ : Initial dry weight $(\mathrm{mg})$ respectively, $\mathrm{t}_{1}$ : initial time, $\mathrm{t}_{2}$ : final time respectively. $\ln : \log , \mathrm{L}_{1}$ and $\mathrm{L}_{2}$ : initial and final leaf area $\left(\mathrm{cm}^{2}\right), \mathrm{W}_{1}$ and $\mathrm{W}_{2}$ : initial and final leaf weight $(\mathrm{mg})$ respectively.

$$
\begin{aligned}
& \text { Simulations } \\
& E_{R G R}=E_{\ln } W_{2}-E_{\ln } W_{1} / t_{2}-t_{1} \\
& S_{R G R}=\sqrt{2}-\sigma \ln w /\left(t_{2}-t_{1}\right) \times \sqrt{n}
\end{aligned}
$$

Where, $E_{R G R}$ : Estimated RGR, $\mu$ lnw: Population mean, olnw: Standard deviation, $\mathrm{S}_{\mathrm{RGR}}$ : Simulated RGR, $\mathrm{E}_{\mathrm{ln}} \mathrm{W}_{1}$ : Mean estimated dry weight of whole plant at time $t_{1}(\mathrm{mg}$ $\mathrm{gm}^{-1}$ day $\left.^{-1}\right), \mathrm{E}_{\mathrm{ln}} \mathrm{W}_{2}$ : Mean estimated dry weight of the whole plant at time $\mathrm{t}_{2}\left(\mathrm{mg} \mathrm{gm}^{-1} \mathrm{day}^{-1}\right)$, n: sample size.

For a general analysis of crops in the field, growth curves have been tested by using Van Krevelen model (Liu et al. 2018).

\section{RESULTS AND DISCUSSION}

\section{Biomass evaluation}

The three weeds exhibited profound inhibitory effects on physical growth of tested crops as elaborated in Figure 1. Plant length (PL) was the most prominently differentiated parameter among all the crops as a function of weed interaction. Maize plants gained highest mean shoot length $(60.4 \pm 4 \mathrm{~cm})$ and highest mean leaf area $\left(19.23 \pm 2.2 \mathrm{~cm}^{2}\right)$ from $5 \mathrm{~g}$ of P. oleracea treated samples. Similarly, Barley plants attained highest mean fresh weight (FW) and dry weight (DW) at $5 \mathrm{~g}$ of $P$. oleracea manure which was $15.3 \pm 2.1 \mathrm{mg}$ and $10.12 \pm 1.6 \mathrm{mg}$ respectively (Figure 1.A). In case of E. hirta and A. viridis, Barley plants attained highest biomass, i.e. $14.23 \pm 1.9 \mathrm{mg}$ : $9.96 \pm$ $1.5 \mathrm{mg}$ and $13.06 \pm 1.6 \mathrm{mg}$ : $9.03 \pm 1.0 \mathrm{mg}$ (FW:DW respectively). While, maize plants achieved higher 
extension in leaf area treated with 5 gm manure of $E$. hirta and $A$. viridis $\left(18.56 \pm 1.9 \mathrm{~cm}^{2}\right.$ and $13.13 \pm 1.5 \mathrm{~cm}^{2}$ respectively) as presented in Figures 1.B and 1.C. The potential of growth in Maize plants was inclined towards leaf area extension observed from E. hirta and A. viridis treated samples contrastingly from other crops rather than shoot length. However, the obtained growth rates were lower in treated plants than in the control samples.

\section{Growth allometry}

Growth allometric equations provided comprehensive information related to the effectiveness of weed impact on crop growth. $P$. oleracea treated Chickpea plants gained highest AGR (29.43 mg day ${ }^{-1}$ ) and carbon content $(15.25 \%)$ from $5 \mathrm{~g}$ and NAR $\left(0.89 \mathrm{~g} \mathrm{~cm}^{2}\right.$ day $\left.^{-1}\right)$ from $15 \mathrm{~g}$ samples. Barley plants attained highest RGR $\left(2.44 \mathrm{mg} \mathrm{gm}^{-1}\right.$ day $^{-1}$ ) from $10 \mathrm{~g}$ treatments (Table 1). Euphorbia hirta treated plants showed a remarkable growth reduction in Pea plants in their AGR (12.36 mg day $\left.{ }^{-1}\right)$, RGR (1.66 mg gm $\mathrm{gm}^{-1}$ day $\left.^{-1}\right)$, and carbon yield $(6.7 \%)$, while the other crops responded with sustainable growth when received mild exposure of E. hirta (Table 2). Similar results were found in crops treated by $A$. viridis that showed highest growth achieved by Barley and Maize crops. While Chickpea plants gained highest NAR $\left(0.89 \mathrm{mg} \mathrm{cm}^{2}\right.$ day $\left.^{-1}\right)$, this indicated a well-maintained photosynthetic activity in their leaves at $15 \mathrm{~g}$ concentration (Table 3 ).
Table 2. Impact of Euphorbia hirta at $5 \mathrm{~g}, 10 \mathrm{~g}$, and $15 \mathrm{~g}$ whole plant powder on growth allometry of maize, barley, pea, chickpea and French beans plants

\begin{tabular}{|c|c|c|c|c|c|}
\hline Treatment & $\begin{array}{c}\text { AGR } \\
\text { mg day } \\
1\end{array}$ & $\begin{array}{c}\text { RGR } \\
\text { mg g }^{-1} \\
\text { day }^{-1}\end{array}$ & $\begin{array}{c}\text { Carbon } \\
\text { content } \\
(\%)\end{array}$ & $\begin{array}{c}\text { LAI } \\
\mathrm{cm}^{2} \mathbf{c m}^{-} \\
1\end{array}$ & $\begin{array}{c}\text { NAR } \\
\text { mg cm}^{2} \\
\text { day }^{-1}\end{array}$ \\
\hline \multicolumn{6}{|l|}{ Maize } \\
\hline Control & 25.52 & 2.29 & 13.3 & 5.09 & 0.13 \\
\hline $5 \mathrm{~g}$ & 20.68 & 2.19 & 10.85 & 5.52 & 0.14 \\
\hline $10 \mathrm{~g}$ & 17.19 & 2.13 & 9.1 & 6.70 & 0.14 \\
\hline $15 \mathrm{~g}$ & 14.09 & 2.01 & 7.55 & 8.69 & 0.15 \\
\hline \multicolumn{6}{|l|}{ Barley } \\
\hline Control & 32.68 & 2.64 & 16.85 & 0.52 & 0.18 \\
\hline $5 \mathrm{~g}$ & 28.82 & 2.40 & 14.95 & 0.54 & 0.19 \\
\hline $10 \mathrm{~g}$ & 23.48 & 2.35 & 12.25 & 0.55 & 0.20 \\
\hline $15 \mathrm{~g}$ & 20.58 & 2.21 & 10.8 & 0.56 & 0.21 \\
\hline \multicolumn{6}{|l|}{ Pea } \\
\hline Control & 25.92 & 2.30 & 13.5 & 0.47 & 0.35 \\
\hline $5 \mathrm{~g}$ & 20.77 & 2.19 & 10.9 & 0.46 & 0.38 \\
\hline $10 \mathrm{~g}$ & 16.04 & 1.87 & 8.55 & 0.47 & 0.39 \\
\hline $15 \mathrm{~g}$ & 12.36 & 1.66 & 6.70 & 0.49 & 0.43 \\
\hline \multicolumn{6}{|l|}{ Chickpea } \\
\hline Control & 34.33 & 2.58 & 17.70 & 0.17 & 0.77 \\
\hline $5 \mathrm{~g}$ & 25.33 & 2.29 & 13.20 & 0.18 & 0.79 \\
\hline $10 \mathrm{~g}$ & 19.72 & 19.72 & 10.40 & 0.20 & 0.86 \\
\hline $15 \mathrm{~g}$ & 14.40 & 14.38 & 7.70 & 0.23 & 0.89 \\
\hline \multicolumn{6}{|l|}{ French beans } \\
\hline Control & 24.55 & 2.29 & 12.80 & 0.51 & 0.22 \\
\hline $5 \mathrm{~g}$ & 20.20 & 2.34 & 10.55 & 0.54 & 0.22 \\
\hline $10 \mathrm{~g}$ & 17.10 & 2.18 & 9.05 & 0.56 & 0.23 \\
\hline $15 \mathrm{~g}$ & 13.72 & 1.70 & 7.40 & 0.60 & 0.24 \\
\hline
\end{tabular}

Table 3. Impact of Amaranthus viridis at $5 \mathrm{~g}, 10 \mathrm{~g}$ and $15 \mathrm{~g}$ whole plant powder on growth allometry of maize, barley, pea, chickpea and French beans plants powder on growth allometry of Maize, Barley, Pea, Chickpea and French beans plants

\begin{tabular}{|c|c|c|c|c|c|}
\hline Treatment & $\begin{array}{c}\text { AGR } \\
\text { mg day }^{-1}\end{array}$ & $\begin{array}{c}\text { RGR } \\
\text { mg g }^{-1} \\
\text { day }^{-1} \\
\end{array}$ & $\begin{array}{c}\text { Carbon } \\
\text { content } \\
(\%) \\
\end{array}$ & $\begin{array}{l}\text { LAI } \\
\mathbf{c m}^{2} \\
\mathrm{~cm}^{-1} \\
\end{array}$ & $\begin{array}{c}\text { NAR } \\
\text { mg cm }^{2} \\
\text { day }^{-1}\end{array}$ \\
\hline \multicolumn{6}{|l|}{ Maize } \\
\hline Control & 25.53 & 2.29 & 13.3 & 0.31 & 0.13 \\
\hline $5 \mathrm{~g}$ & 23.38 & 2.32 & 12.2 & 0.32 & 0.14 \\
\hline $10 \mathrm{~g}$ & 21.59 & 2.35 & 11.3 & 0.34 & 0.14 \\
\hline $15 \mathrm{~g}$ & 16.69 & 2.32 & 10.35 & 0.60 & 0.15 \\
\hline \multicolumn{6}{|l|}{ Barley } \\
\hline Control & 32.68 & 2.63 & 16.85 & 0.53 & 0.18 \\
\hline $5 \mathrm{~g}$ & 29.32 & 2.42 & 15.2 & 0.52 & 0.19 \\
\hline $10 \mathrm{~g}$ & 25.78 & 2.44 & 13.4 & 0.55 & 0.20 \\
\hline $15 \mathrm{~g}$ & 23.08 & 2.32 & 12.05 & 0.59 & 0.21 \\
\hline \multicolumn{6}{|l|}{ Pea } \\
\hline Control & 25.92 & 2.30 & 13.5 & 0.47 & 0.35 \\
\hline $5 \mathrm{~g}$ & 24.27 & 2.34 & 12.65 & 0.47 & 0.38 \\
\hline $10 \mathrm{~g}$ & 20.64 & 2.11 & 10.85 & 0.53 & 0.39 \\
\hline $15 \mathrm{~g}$ & 17.16 & 1.96 & 9.10 & 0.55 & 0.43 \\
\hline \multicolumn{6}{|l|}{ Chickpea } \\
\hline Control & 34.33 & 2.58 & 17.70 & 0.17 & 0.77 \\
\hline $5 \mathrm{~g}$ & 29.43 & 2.43 & 15.25 & 0.18 & 0.79 \\
\hline $10 \mathrm{~g}$ & 25.12 & 2.27 & 13.10 & 0.18 & 0.86 \\
\hline $15 \mathrm{~g}$ & 22.18 & 2.31 & 11.60 & 0.21 & 0.89 \\
\hline \multicolumn{6}{|c|}{ French beans } \\
\hline Control & 24.55 & 2.29 & 12.80 & 0.51 & 0.22 \\
\hline $5 \mathrm{~g}$ & 21.49 & 2.41 & 11.25 & 0.53 & 0.22 \\
\hline $10 \mathrm{~g}$ & 17.79 & 2.22 & 9.40 & 0.56 & 0.23 \\
\hline $15 \mathrm{~g}$ & 15.02 & 1.78 & 8.05 & 0.59 & 0.24 \\
\hline
\end{tabular}

\begin{tabular}{|c|c|c|c|c|c|}
\hline Treatment & $\begin{array}{c}\text { AGR } \\
\text { mg day }^{-1}\end{array}$ & $\begin{array}{c}\text { RGR } \\
\text { mg g-1 }^{-1} \\
\text { day }^{-1}\end{array}$ & $\begin{array}{c}\text { Carbon } \\
\text { content } \\
(\%)\end{array}$ & $\underset{\mathbf{c m}^{2} \mathbf{c m}^{-1}}{\text { LAI }}$ & $\begin{array}{c}\text { NAR } \\
\text { mg cm }_{\text {day }^{-1}}\end{array}$ \\
\hline \multicolumn{6}{|l|}{ Maize } \\
\hline Control & 25.53 & 2.29 & 13.3 & 5.09 & 0.13 \\
\hline $5 \mathrm{~g}$ & 19.53 & 2.04 & 10.30 & 6.62 & 0.14 \\
\hline $10 \mathrm{~g}$ & 14.39 & 1.90 & 7.70 & 8.10 & 0.14 \\
\hline $15 \mathrm{~g}$ & 13.43 & 1.69 & 7.25 & 8.20 & 0.15 \\
\hline \multicolumn{6}{|l|}{ Barley } \\
\hline Control & 32.68 & 2.64 & 16.85 & 0.53 & 0.18 \\
\hline $5 \mathrm{~g}$ & 26.09 & 2.59 & 13.55 & 0.55 & 0.19 \\
\hline $10 \mathrm{~g}$ & 22.14 & 2.17 & 11.60 & 0.58 & 0.20 \\
\hline $15 \mathrm{~g}$ & 19.72 & 2.04 & 10.40 & 0.59 & 0.21 \\
\hline \multicolumn{6}{|l|}{ Pea } \\
\hline Control & 25.92 & 2.30 & 13.5 & 0.47 & 0.35 \\
\hline $5 \mathrm{~g}$ & 17.10 & 2.18 & 9.05 & 0.51 & 0.38 \\
\hline $10 \mathrm{~g}$ & 11.57 & 1.67 & 6.29 & 0.44 & 0.39 \\
\hline $15 \mathrm{~g}$ & 8.33 & 1.42 & 4.67 & 0.46 & 0.43 \\
\hline \multicolumn{6}{|l|}{ Chickpea } \\
\hline Control & 34.33 & 2.58 & 17.70 & 0.17 & 0.77 \\
\hline $5 \mathrm{~g}$ & 21.45 & 2.17 & 11.25 & 0.18 & 0.79 \\
\hline $10 \mathrm{~g}$ & 15.75 & 1.86 & 8.40 & 0.20 & 0.86 \\
\hline $15 \mathrm{~g}$ & 11.09 & 1.78 & 6.05 & 0.23 & 0.89 \\
\hline \multicolumn{6}{|c|}{ French beans } \\
\hline Control & 24.55 & 2.29 & 12.80 & 0.51 & 0.22 \\
\hline $5 \mathrm{~g}$ & 17.19 & 2.19 & 9.10 & 0.54 & 0.22 \\
\hline $10 \mathrm{~g}$ & 14.39 & 1.90 & 7.70 & 0.61 & 0.23 \\
\hline $15 \mathrm{~g}$ & 11.02 & 1.50 & 6.05 & 0.65 & 0.24 \\
\hline
\end{tabular}



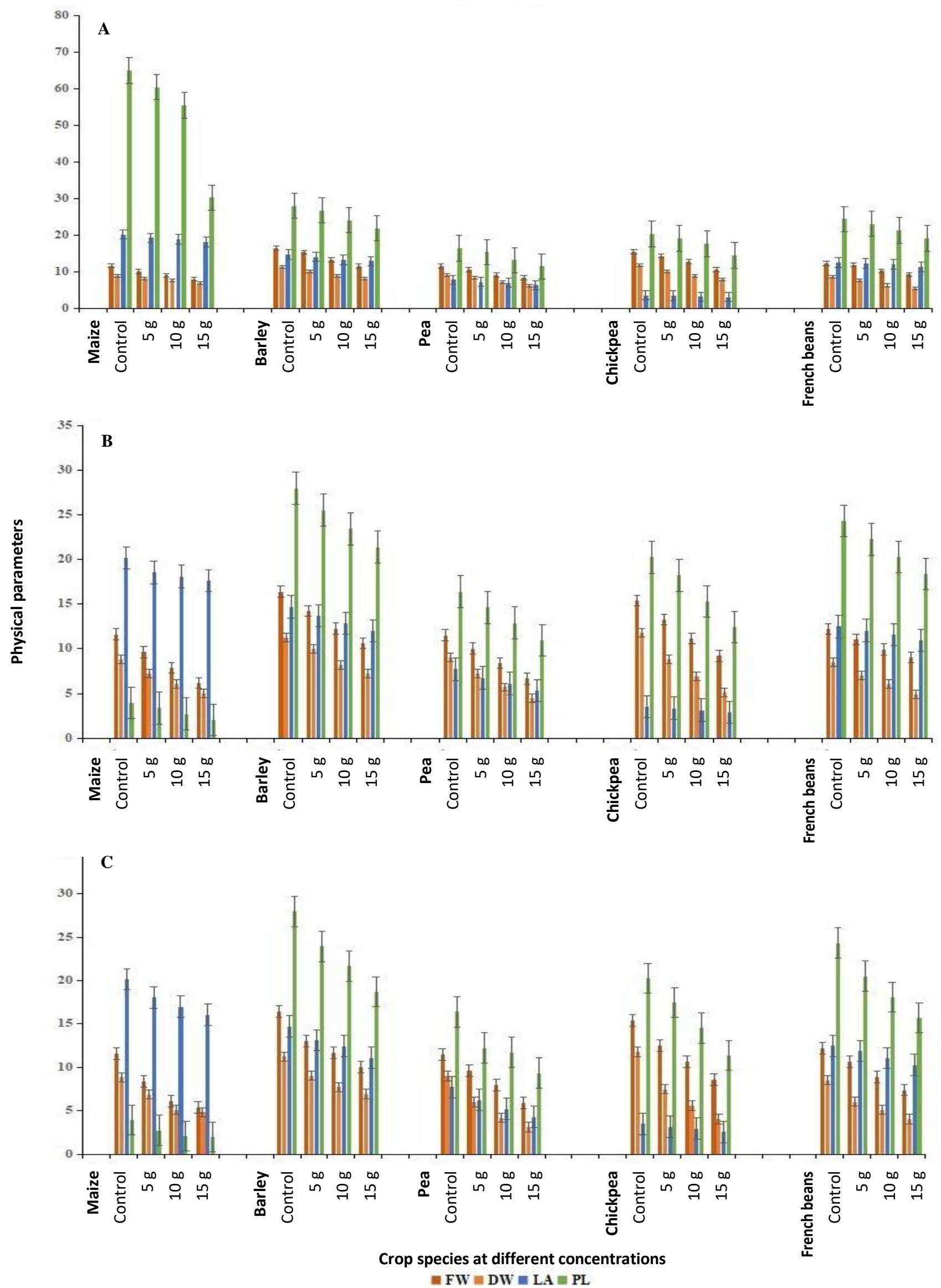

Figure 1. Effect of Portulaca oleracea (A), Euphorbia hirta (B), and Amaranthus viridis (C) at various concentrations in crops respectively. Note: DW: Dry weight, FW: Fresh weight, LA: Leaf area, PL: Plant length 

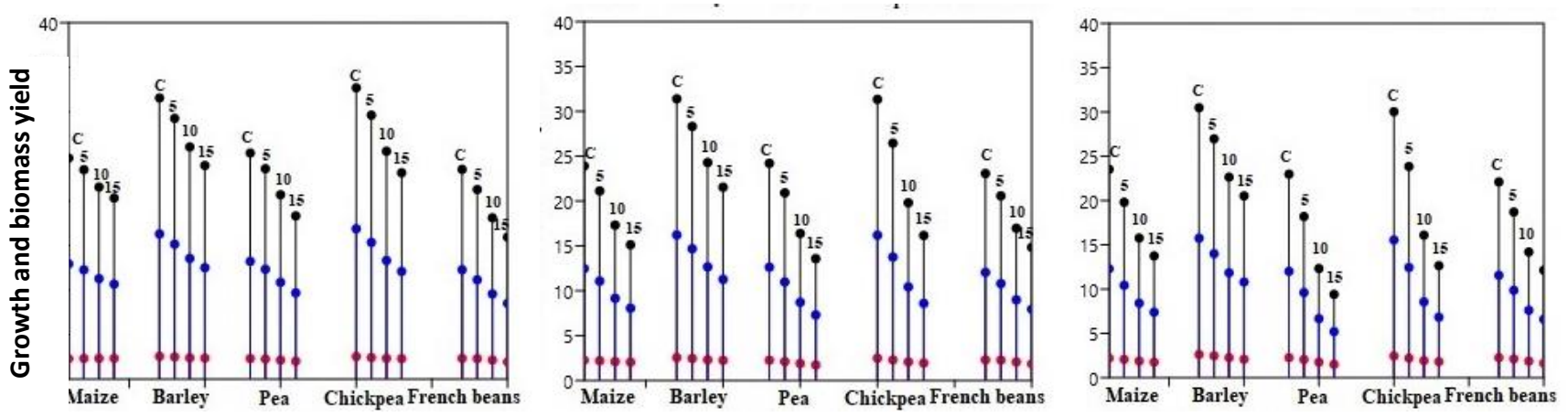

Crop with concentration (g)

A

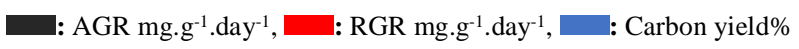

B

C

Figure 2. AGR, RGR, and carbon yield estimations of tested crops at different weed concentrations. Note: C: Control, 5: 5\%, 10: 10\%, 15: 15\%; A. Portulaca oleracea, B. Euphorbia hirta, C. Amaranthus viridis

Table 4. Influence of different weeds on correlation between plant height versus dry weight and plant height vs leaf area of maize, barley, pea, chick pea and French beans plants

\begin{tabular}{|c|c|c|c|c|c|c|}
\hline \multirow{2}{*}{ Crop species } & \multicolumn{2}{|c|}{ PO } & \multicolumn{2}{|c|}{ EH } & \multicolumn{2}{|c|}{$\mathbf{A V}$} \\
\hline & PL/DW(\%) & PL/LA(\%) & PL/DW(\%) & PL/LA(\%) & PL/DW(\%) & PL/LA(\%) \\
\hline Maize & 69 & 64 & 47 & 57 & 87 & $91^{*}$ \\
\hline Barley & $91^{*}$ & 86 & $95^{* *}$ & $93^{*}$ & $96^{* *}$ & $96^{* *}$ \\
\hline Pea & $96^{* * *}$ & 71 & $94^{* *}$ & 81 & 88 & $91^{*}$ \\
\hline Chickpea & 78 & 76 & $95^{* *}$ & $96^{* *}$ & $92^{*}$ & 90 \\
\hline French beans & $96^{* * *}$ & $92^{*}$ & $97^{* * * *}$ & $99^{* * * *}$ & $96^{* * *}$ & $93^{*}$ \\
\hline
\end{tabular}

Note: $*$ p < $0.5, * *: p<0.01, * *: p<0.001 * * *$

A comparative illustration of growth allometry with respect to weed activity impact on crops presented in Figure 2. AGR, RGR, and carbon yield were of main concern as the final resultants of plant metabolic activity, summarized in Figure 2. Barley and chickpea plants attained the highest growth under the influence of the three weeds. However, the estimations were too close and can not produce a considerable difference in the effectiveness of weeds, $A$. viridis was found to be the strongest inhibitory weed among these crops.

Relationship of the physical parameters was analyzed for the assessment of growing trends in crops under the weed influence (Table 4). Interestingly, French beans have produced a highly significant $(\mathrm{p}<0.001)$ relationship between plant length and dry weight as well as in plant length and leaf area in E. hirta treated samples (Figure 4.E) while significant ( $\mathrm{p}<0.01$, and $\mathrm{p}<0.5$, respectively) in $P$. oleracea and A. viridis treatments (Figures 3.E and 5.E respectively). While analyzing $E$. hirta and $A$. viridis treated plants, Chickpeas showed significant $(\mathrm{p}<0.01$, and $\mathrm{p}<0.5$, respectively) relationship with predefined parameters whereas non-significant in P. oleracea samples (Figure 3d). Likewise, Barley plants have also produced significant $(\mathrm{p}<0.01, \mathrm{p}<0.5)$ relationship in all the treatments with the exception of a non-significant relationship between leaf area and plant length with $P$. oleracea treated samples (Table 4, Figures 3.B, 4.B and 5.B). On the other hand, Maize plants showed significant relation $(\mathrm{p}<0.5)$ with plant length and leaf area in $A$. viridis treated plants while the rest samples showed nonsignificant results (Figures 3.A, 4.A, and 5.A).
Carbon and carbon-based products are the final metabolic resultants that are dependant on the photosynthetic activity performed by plants. The relative influence of weeds have been analyzed and compared in Figure 6. Carbon content of all plants was significantly decreased under the influence of the weeds. A. viridis has strongly inhibited NAR and carbon yield of the crops in comparison to the other weeds (Figure 6).

\section{Simulations}

A hypothetical field condition of the given crops growing with the predefined weeds has been endured in this section. A standardized field condition of 1000 plants of each crop could provide an estimation of relative biomass into agriculture and environment as mentioned under the heads of Estimated and Standard RGR per day (Table 3). Portulaca oleracea did not produce any devastating outputs, Maize crops showed increased $E_{\text {RGR }}$ with the increase in concentration, while Barley, Chickpea, Pea and French bean samples consecutively decreased their biomass when they received higher weed concentration. In addition, $S_{R G R}$ decreased in all crops with increase in concentration. STDev was considerably weak i.e., below $0.5 \%$, hence no effective deviation except that of Chickpea samples (1.01) from 10\% samples (Table 5) can be seen. Similarly, $\mathrm{E}_{\mathrm{RGR}}$ and $\mathrm{S}_{\mathrm{RGR}}$ of E. hirta and A. viridis treated samples estimated lowest amount of organic matter in the field even with a massive number of samples. STDev was too low in both the weed effects indicating that they possessed lower capability to deviate under such stress (Tables 6 and 7). 
Table 5. Effect of Portulaca oleracea on simulations of the tested species
Table 7. Effect of Amaranthus viridis on simulations of the tested species

\begin{tabular}{|c|c|c|c|c|c|c|c|}
\hline Treatment & $\begin{array}{c}\text { E }_{\text {RGR }} \\
\text { mg g }^{-1} \text { day }^{-1}\end{array}$ & $\begin{array}{c}\text { S }_{\text {RGR }} \\
\text { mg g }^{-1} \text { day }^{-1}\end{array}$ & STDEV & Treatment & $\begin{array}{c}\text { E }_{\text {RGR }} \\
\text { mg g }^{-1} \text { day }^{-1}\end{array}$ & $\begin{array}{c}\text { SRGR }_{\text {RGR }} \\
\text { mg g }^{-1} \text { day }^{-1}\end{array}$ & STDEV \\
\hline Maize & & & & Maize & & & \\
\hline Control & 1.19 & 3.91 & 0.06 & Control & 1.19 & 3.91 & 0.06 \\
\hline $5 \mathrm{~g}$ & 1.22 & 3.91 & 0.06 & $5 \mathrm{~g}$ & 0.94 & 3.91 & 0.06 \\
\hline $10 \mathrm{~g}$ & 1.25 & 3.91 & 0.06 & $10 \mathrm{~g}$ & 0.81 & 3.91 & 0.06 \\
\hline $15 \mathrm{~g}$ & 1.22 & 3.78 & 0.1 & $15 \mathrm{~g}$ & 0.59 & 3.18 & 0.31 \\
\hline Barley & & & & Barley & & & \\
\hline $5 \mathrm{~g}$ & 1.31 & 3.91 & 0.06 & $5 \mathrm{~g}$ & 1.49 & 3.74 & 0.12 \\
\hline $10 \mathrm{~g}$ & 1.34 & 3.63 & 0.15 & $10 \mathrm{~g}$ & 1.07 & 3.47 & 0.21 \\
\hline $15 \mathrm{~g}$ & 1.22 & 2.14 & 0.66 & $15 \mathrm{~g}$ & 0.94 & 3.63 & 0.15 \\
\hline Pea & & & & Pea & & & \\
\hline Control & 1.21 & 3.78 & 0.1 & Control & 1.21 & 3.78 & 0.1 \\
\hline $5 \mathrm{~g}$ & 1.24 & 3.18 & 0.31 & $5 \mathrm{~g}$ & 1.08 & 3.74 & 0.12 \\
\hline $10 \mathrm{~g}$ & 1.01 & 3.63 & 0.15 & $10 \mathrm{~g}$ & 0.57 & 2.95 & 0.39 \\
\hline Chick pea & & & & Chickpea & & & \\
\hline Control & 1.48 & 3.78 & 0.1 & Control & 1.48 & 3.78 & 0.1 \\
\hline $5 \mathrm{~g}$ & 1.34 & 3.91 & 0.01 & $5 \mathrm{~g}$ & 1.07 & 3.02 & 0.36 \\
\hline $10 \mathrm{~g}$ & 1.17 & 1.13 & 1.01 & $10 \mathrm{~g}$ & 0.76 & 3.2 & 0.3 \\
\hline $15 \mathrm{~g}$ & 1.22 & 2.69 & 0.47 & $15 \mathrm{~g}$ & 0.68 & 3.14 & 0.32 \\
\hline French beans & & & & French beans & & & \\
\hline Control & 1.20 & 3.63 & 0.15 & Control & 1.19 & 3.63 & 0.15 \\
\hline $5 g$ & 1.31 & 3.78 & 0.1 & $5 g$ & 1.09 & 3.63 & 0.15 \\
\hline $10 \mathrm{~g}$ & 1.13 & 3.63 & 0.15 & $10 \mathrm{~g}$ & 0.81 & 3.34 & 0.25 \\
\hline $15 \mathrm{~g}$ & 0.69 & 3.91 & 0.06 & $15 \mathrm{~g}$ & 0.39 & 3.4 & 0.23 \\
\hline
\end{tabular}

Table 6. Effect of Euphorbia hirta on simulations of the tested species

\begin{tabular}{lccc}
\hline Treatment & $\begin{array}{c}\mathbf{E}_{\mathbf{R G R}} \\
\mathbf{m g ~}^{-1} \mathbf{d a y}^{\mathbf{- 1}}\end{array}$ & $\begin{array}{c}\mathbf{S}_{\mathbf{R G R}} \\
\mathbf{m g ~ g}^{-1} \mathbf{d a y}^{-1}\end{array}$ & STDEV \\
\hline Maize & & & \\
Control & 1.19 & 3.91 & 0.06 \\
$5 \mathrm{~g}$ & 1.10 & 3.73 & 0.12 \\
$10 \mathrm{~g}$ & 1.04 & 3.63 & 0.15 \\
$15 \mathrm{~g}$ & 0.91 & 3.74 & 0.12 \\
Barley & & & \\
Control & 1.54 & 2.39 & 0.57 \\
$5 \mathrm{~g}$ & 1.30 & 3.74 & 0.12 \\
$10 \mathrm{~g}$ & 1.25 & 3.74 & 0.12 \\
$15 \mathrm{~g}$ & 1.11 & 3.78 & 0.1 \\
Pea & & & \\
Control & 1.21 & 3.78 & 0.1 \\
$5 \mathrm{~g}$ & 1.10 & 3.23 & 0.28 \\
$10 \mathrm{~g}$ & 1.00 & 3.30 & 0.26 \\
$15 \mathrm{~g}$ & 0.55 & 3.34 & 0.25 \\
Chickpea & & & \\
Control & 1.49 & 3.78 & 0.1 \\
$5 \mathrm{~g}$ & 1.19 & 3.78 & 0.1 \\
$10 \mathrm{~g}$ & 0.94 & 3.63 & 0.15 \\
$15 \mathrm{~g}$ & 0.81 & 3.91 & 0.06 \\
French beans & & & \\
Control & 1.19 & 3.63 & 0.15 \\
$5 \mathrm{~g}$ & 1.24 & 3.74 & 0.12 \\
$10 \mathrm{~g}$ & 1.09 & 3.74 & 0.12 \\
$15 \mathrm{~g}$ & 0.60 & 3.63 & 0.15 \\
\hline
\end{tabular}

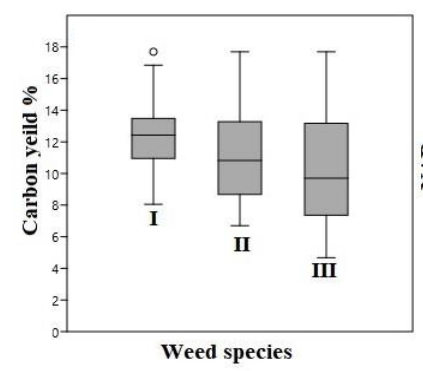

A

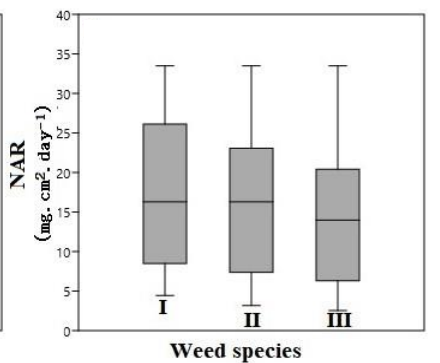

B

Figure 6. Comparative analysis of carbon yield (a) and Net assimilation rate [(NAR), (b)] of all tested plants under weed stress respectively. I: Portulaca oleracea, II: Euphorbia hirta, III: Amaranthus viridis

The effected crops cumulatively tested for hypothetical model development to analyze organic yield, data followed poor growth and a declined state as their growth forecast, whereas the control samples followed Deevy II type curve as represented in Figure 7 (A, B and C) for P. oleracea, E. hirta and $A$. viridis respectively.

\section{Discussion \\ Biomass and growth}

Growth attainment is a function of plant productivity or biomass gain. Allometric studies on plant growth elucidate the physiological performance of plants. Fundamental approach for growth evaluation in plants has been focused 
on the elevated levels of carbon as a result of enhanced photosynthetic rate (Kanwal et al. 2018; Muller et al. 2011; Hummel et al. 2010). There are several studies on biomass yield performance of trees and crops (Asad et al. 2020). However, these studies explained the criterion of growth over the short-term period. Present study demonstrated the allelopathic effect of three weeds on five different crops at seedling stage. Bio-chemicals in the weeds that are growing with crops, have a specialized mechanism which can cause inhibition on growth and metabolism, fresh and dry matter along with decreasing level of carbon content of crop plants (Zhu et al. 2010). Weed manure incorporated into soil could decrease the soil essential elements due to the presence of certain phenolic compounds that have been resulted in the reduction of plant height, biomass content and yield of leguminous crops i.e., Chickpea (Amaral et al. 2018). Amounts of biochemicals vary from one part to another part of the same weed, and their effects could also be variable within the same crop species (Khan et al. (2018). Shaukat et al. (2001) and Noshad and Khan (2019) reported that the higher amount of weed manure could reduce fresh and dry weight of the tested species, while at low level it may enhance the metabolic activities of the recipient plant

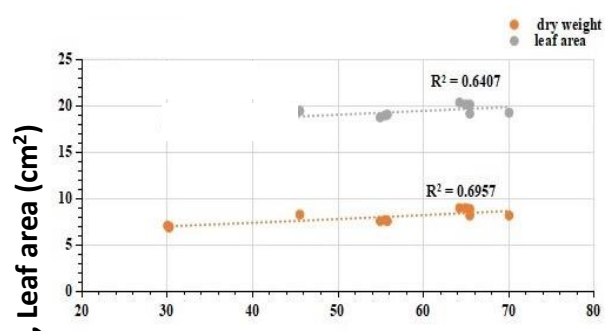

A

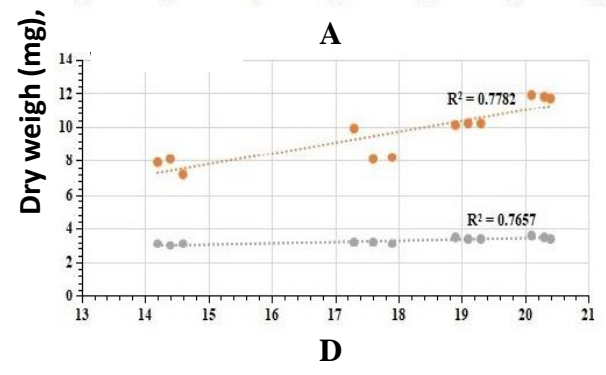

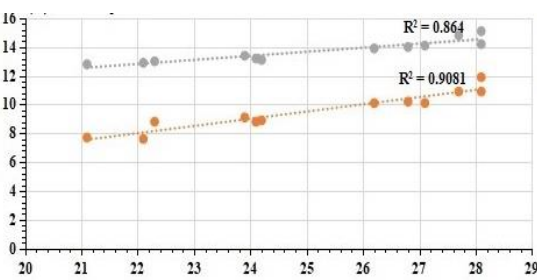

B

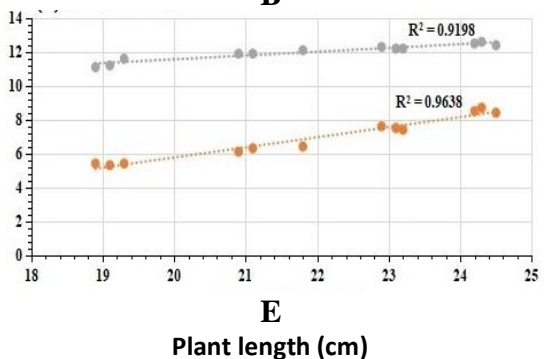

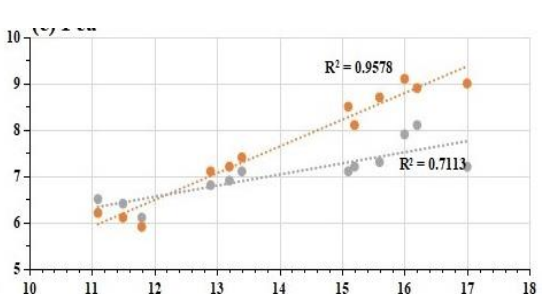

C

Figure 3. Relationship between dry weight and leaf area of crops growing under influence of Portulaca oleracea. Note: A. Maize, B. Barley, C. Pea, D. Chickpea, E. French beans
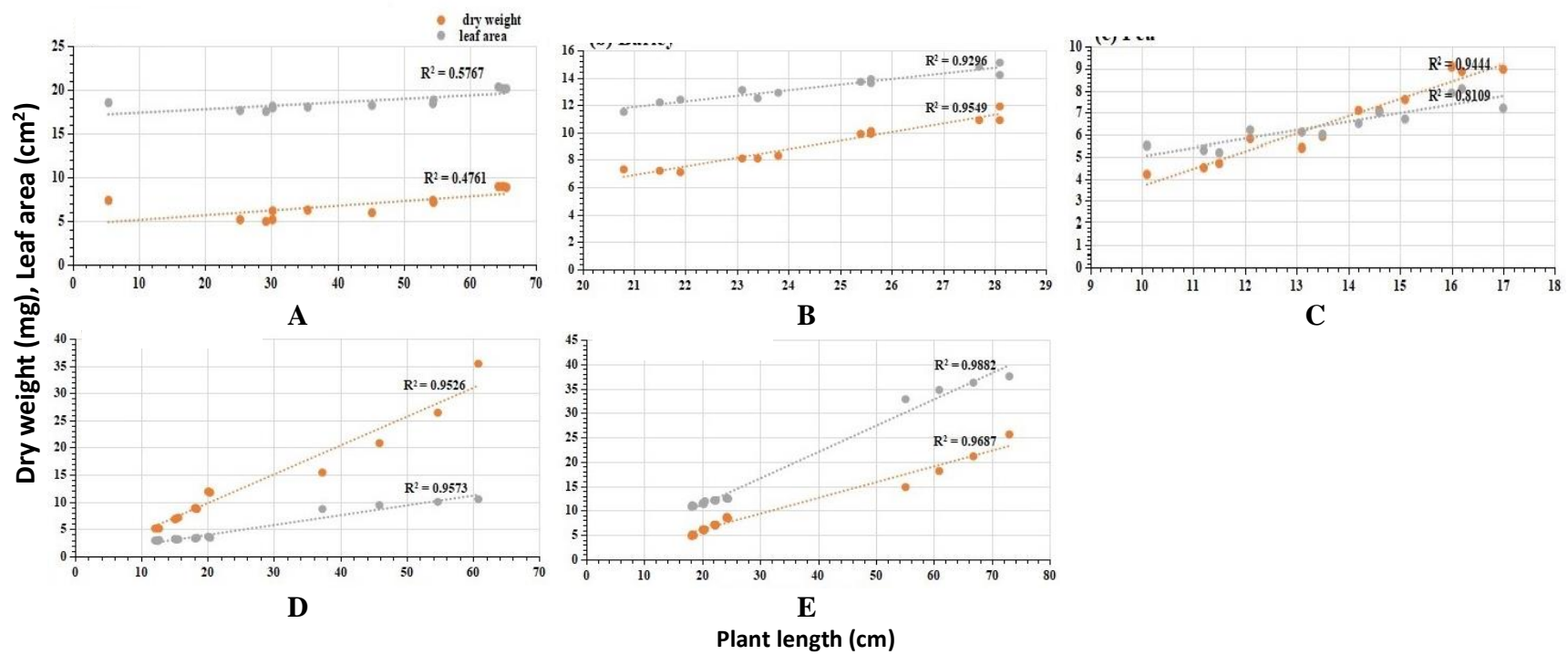

Figure 4. Relationship between dry weight and leaf area of crops growing under influence of Euphorbia hirta 

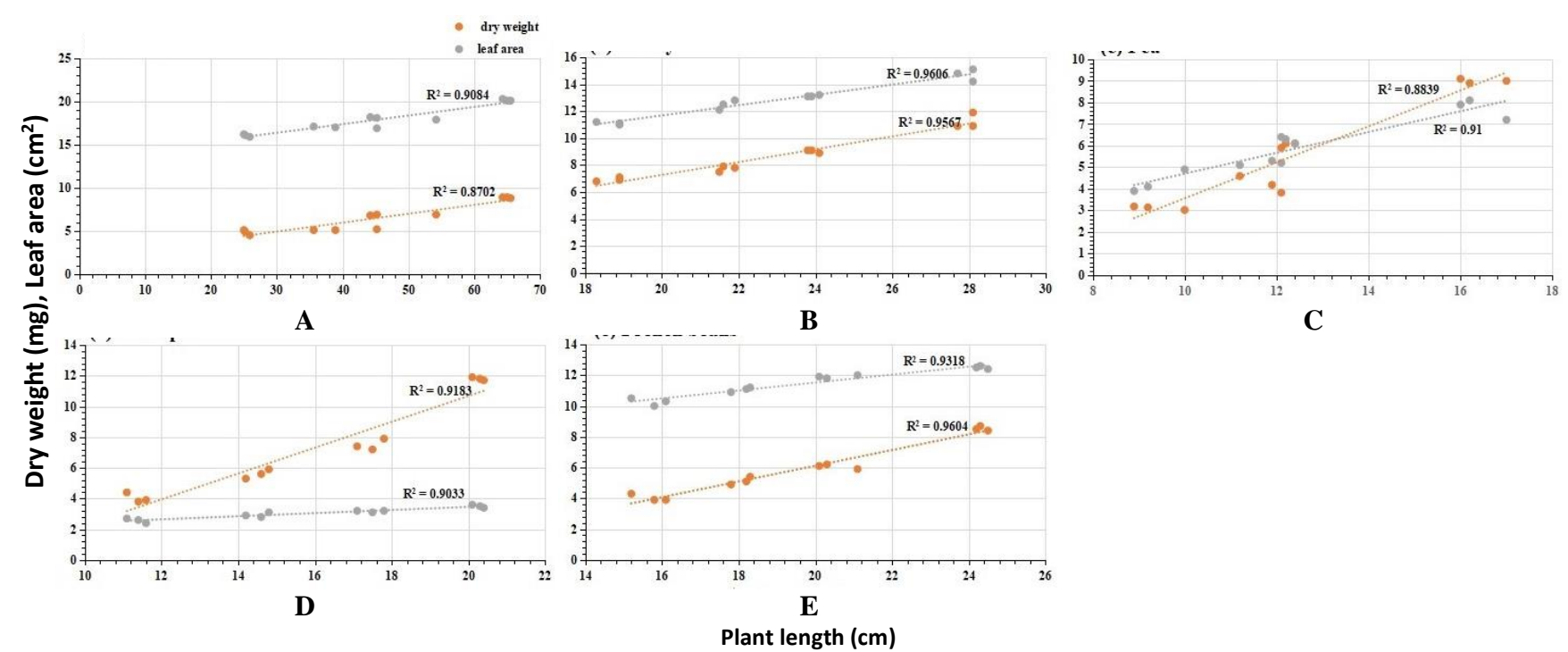

Figure 5. Relationship between dry weight and leaf area of crops growing under influence of Amaranthus viridis
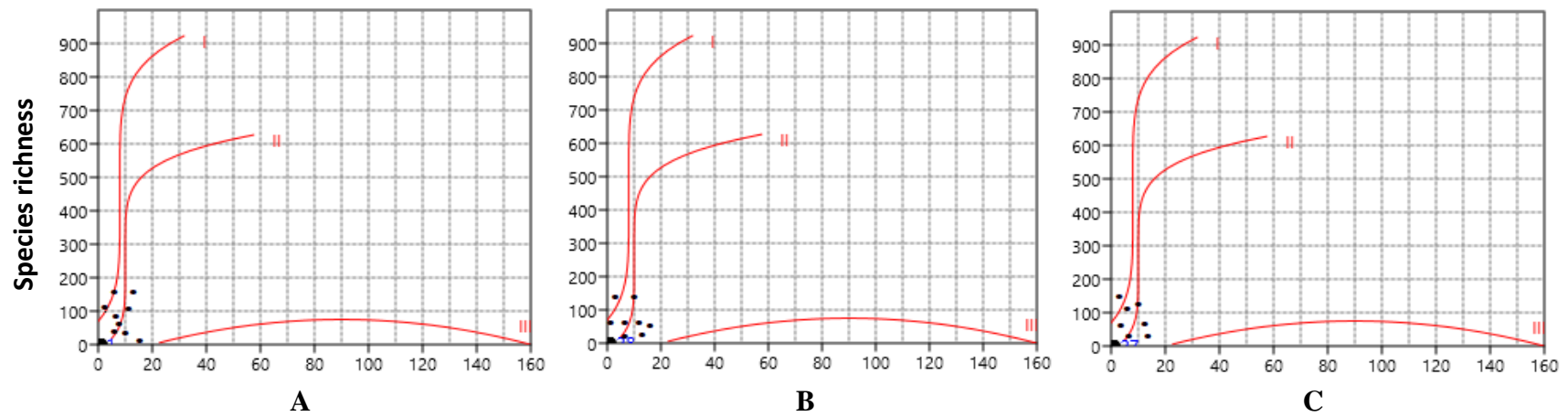

Figure 7. Growth curve of crops under weed stress of: A. Portulaca oleracea, B. Euphorbia hirta, C. Amaranthus viridis. Note: I, II, and III are indicators of Deevy type curves

Current findings suggested that Barley and Chickpea are the most successfully sustained crops in the presence of predefined weeds. Plant growth is basically expressed as absolute growth rate (AGR) that evaluates the changes in plant growth over time $(\mathrm{t})$. Linearity in growth expression indicates a constant increase in plant size (Poorter et al. 2013). The concept of AGR sometimes could not fit or less explanatory at juvenille stage of plants. Another fraction of biomass evaluation employed in allometric algorithms is relative growth rate (RGR), the concept engrains the projection of plant growth allometric fluctuations (Poorter et al. 2013). RGR concept proposes exponential growth trajectories during the time span encompassing the variabilities in all stages (Blackman 1919). However, AGR provides the proportional value of plant biomass already present whereas, RGR can be adequately served for the assessment of fluctuations in mass gain at different stages (Palosuo et al. 2011). These fluctuations can be indicated by non-linear trends as plants invested their synthesized energy and resources on different body components like stems, leaves production and area enlargement, flower production, etc. In the present study, RGR has been focused because of the utilization of crop seedlings for allometric investigations; for being a crucial stage in plant survivorship. Assuming seedlings for their tolerance optimum limit, the biomass and green matter attainment capability and survival potential under stress claimed high degree of vulnerability in crop seedlings.

The progression of RGR has been further factorized into some other underlying components i.e., carbon yield, leaf area ratio (LAR), net assimilation rate (NAR). The later components (LAR, NAR) are supposed to be the strongly correlated fractions with metabolism particularly photosynthesis and therefore with the ultimate resultant i.e., carbon content (Poorter et al. 2010). Relative increase in the leaf area and assimilation by leaves have sought to increase carbon yield and biomass (Evers et al. 2011).

The effect of weeds has been studied extensively in the past in which most of the studies claim for inhibitory characteristics of weeds while the lower amount of literature has been devoted to the biomass effects. Therefore, it is important to study the comparative biomass 
contribution of crops grown with the weeds.

\section{Simulations}

Generally, the total dry weight of plants in a population used for biomass evaluation at the final time $(\mathrm{t})$, as the conventional dry weight distribution of plants found to be a non-normal pattern (Palosuo et al. 2011; Rötter et al. 2012). The acquisition of the normalized distribution involved the utilization of parametric algorithms like analysis of variance (in case of non-log values and means) as well as data transformation to $\ln$ (for $\log$ of data values and means). The means of dry weights are homogenized for comparison in the form of $\ln$ transformed version that has employed standard deviation $(\sigma)$ which could generate an alert for a timely persuasive event (Renton and Poorter 2011). Therefore, the geometric unbiased mean could be more effective for computation of a log-normal distribution (Poorter and Garnier 1998; Poorter et al. 2012). In the current study, test crops have been hypothetically designed in a population growing under given weed stress. The relative influence of weeds simulated in the van-Krevelen curves in which tested crops were supposed to follow Deevy type II curves, as the control samples did, but the treatments have failed to follow any of the given types. The weed stress on all the tested crops appeared to be too harsh indicating certain declining threat to the agricultural field of all the crops under such conditions.

\section{REFERENCES}

Abbas T, Tanveer A, Khaliq A, Safdar ME, Nadeem MA. 2014 Allelopathic effects of aquatic weeds on germination and seedling growth of wheat. Herb 14 (2): 11-25. DOI: 10.5644/Herb.14.2.02.

Amaral CL, Pavan GB, Pereira FCM, Alves PLDCA. 2018. Periods of weed interference in chickpea grown under different doses of nitrogen fertilizer topdressing. Acta Scientiarum Agronomy 40: 1807-8621. DOI: 10.4025 /actasciagron.v40i1.35666.

Asad M, Khan A, Jahan B. 2020. Variation in biomass production of sunflower (Helianthus annuus) plants under the influence of Lemongrass (Cymbopogon erectus) extract. Turkish J Biodiversity 3 (2): 54-59. DOI: 10.38059/biodiversity.729081.

Blackman VH. 1919. The compound interest law and plant growth. Ann Bot 33: 353-360. DOI: 10.1093/oxfordjournals.aob.a089727.

Dafaallah AB, Yousif MH, Abdelrahman AO. 2019. Allelopathic effects of pigweed (Amaranthus viridis L.) on seed germination and seedling growth of some leguminous crops. Intl J Innov Approach Agric Res. 3 (4): 566-577 DOI: 10.29329/ijiaar.2019.217.3.

El-Rokiek KG, Abdelhamid MT, El-Din SS. 2013. Physiological response of purslane weed (Portulaca oleracea) and two common beans (Phaseolus vulgaris) recombinant inbred lines to phosphorus fertilizer and bentazon herbicide. J Appl Sci Res 9 (4): 2743-2749.

Evers JB, VanderKro 1AR, Vos J, Struik PC. 2011. Understanding shoot branching by modelling form and function. Trends Plant Sci 16: 464467.

Hood EE, Teoh K, Devaiah SP, Requesens DV. 2012. Biomass Crops for Biofuels and Bio-based Products. In: Meyers RA (eds.) Encyclopedia of Sustainability Science and Technology. Springer, New York, NY. DOI: 10.1007/978-1-4419-0851-3_170

Hummel I, Pantin F, Sulpice R, et al. 2010. Arabidopsis plants acclimate to water deficit at low cost through changes of carbon usage: an integrated perspective using growth, metabolite, enzyme, and gene expression analysis. Plant Physiol 154: 357-372.

Kanwal S, Batool A, Ghufran MA, Khalid A. 2018. Effect of dairy manure derived biochar on microbial biomass carbon, soil carbon and Vitis vinifera under water stress conditions. Pak J Bot 50 (5): 17131718.
Khan A, Ahmed M, Ahmed F, Saeed R, Siddiqui F. 2020. Vegetation of highly disturbed conifer forests around Murree, Pakistan. Turkish J Biodiversity 3 (2): 43-53. DOI: 10.38059/biodiversity.708154.

Khan A, Ahmed M, Shaukat SS. 2018. Allelopathy: An overview. FUUAST J Biol 8 (2): 331-350.

Kumar N, Yadav A. 2018. Role of Pulses in Improving Soil Quality and Enhancing Resource Use Efficiency. Today \& Tomorrow's Printers and Publishers, India.

Li G, Liu C, Yu Z, Rao M, Zhong Q, Zhang Y, Jiang T. 2018. Energy saving of composite agglomeration process (CAP) by optimized distribution of pelletized feed. Energies 11: 2382.

Liu JH, Yan Y, Ali A et al. 2018. Simulation of crop growth, time to maturity and yield by an improved sigmoidal model. Sci Rep 8: 7030. DOI: 10.1038/s41598-018-24705-4.

Muller B, Pantin F, Génard M, Turc O, Freixes S, Piques M. and Gibon Y. 2011. Water deficits uncouple growth from photosynthesis, increase $C$ content, and modify the relationships between $\mathrm{C}$ and growth in sink organs. J Exp Bot 62: 1715-1729.

Noshad S, Khan A. 2019. Recovery in growth of Solanum melongena. L from adverse effects of wastewater effluents. FUUAST J Biol 9 (1): 33-39.

Paine CET, Marthews TR, Vogt DR, Purves D, Rees M, Hector A, Turnbull LA. 2012. How to fit nonlinear plant growth models and calculate growth rates: An update for ecologists. Methods Ecol Evol 3: 245-256. DOI: 10.1111/j.2041-210X.2011.00155.x.

Palosuo T, Kersebaum KC, Angulo C, Hlavinka P, Moriondo M, Olesen JE et al. 2011. Simulation of winter wheat yield and its variability in different climates of Europe: a comparison of eight crop growth models. Eur J Agron 35: 103-114.

Poorter H, Van der Werf A. 1998. Is inherent variation in RGR determined by LAR at low irradiance and by NAR at high irradiance? A review of herbaceous species. In: Lambers H, Poorter H, Van Vuuren MMI (eds.). Inherent Variation in Plant Growth. Physiological Mechanisms and Ecological Consequences, Backhuys Publishers, Leiden.

Poorter H, Anten NPR, Marcelis LFM. 2013. Physiological mechanisms in plant growth models: do we need a supra-cellular systems biology approach? Plant Cell Environ 36: 1673-1690. DOI: $10.1111 /$ pce. 12123

Poorter H, Niklas KJ, Reich PB, Oleksyn J, Poot P. and Mommer L. 2012. Biomass allocation to leaves, stems and roots: meta-analyses of interspecific variation and environmental control. New Phytol 193: $30-50$

Poorter H, Niinemets Ü, Walter A, Fiorani F. and Schurr U. 2010. A method to construct dose-response curves for a wide range of environmental factors and plant traits by means of a meta-analysis of phenotypic data. J Exp Bot 61: 2043-2055.

Rajput BS, Bhardwaj DR, Pala NA. 2017. Factors influencing biomass and carbon storage potential of different land-use systems along an elevational gradient in temperate northwestern Himalaya. Agrofor Syst 91: 479-486. DOI: 10.1007/s10457-016-9948-5

Rötter RP, Palosuo T, Kersebaum KC, et al. 2012. Simulation of spring barley yield in different climatic zones of Northern and Central Europe: a comparison of nine crop models. Field Crops Res 133: 2336.

Shaukat SS, Siddiqui IA. 2001. Lantana camara in the soil changes the fungal community structure and reduces impact of Meloidogyne javanica on mungbean. Phytopathol Mediterranean. 40: 245-252.

Renton M. and Poorter H. 2011. Using log-log scaling slope analysis for determining the contributions to variability in biological variables such as leaf mass per area (LMA): why it works, when it works and how it can be extended. New Phytologist 190: 5-8.

Tanveer A, Khaliq A, Javaid MM, Chaudhry MN, Awan I. 2013. Implications of weeds of genus euphorbia for crop production: a review. Planta Daninha 31 (3): 723-731. DOI: 10.1590/S010083582013000300024

Thomas SC, Martin AR. 2012. Carbon content of tree tissues: A synthesis. Forests 3 (2): 332-352. DOI: 10.3390/f3020332.

Zhu XG, Long SP, Ort DR. 2010. Improving photosynthetic efficiency for greater yield. Ann Rev Plant Biol 61: 235-261.

Zohaib A, Tabassum T, Anjum SA, Abbas T, Nazir U. 2017. Allelopathic Effect of Some Associated Weeds of Wheat on Germinability and Biomass Production of Wheat Seedlings. Planta Daninha 35: 18069681. DOI. DOI: 10.1590/s0100-83582017350100089. 